\title{
日本における株式会社の成立と会社規制 ——旧商法施行前における地方官庁の果たした役割
}

北 浦 貴 士

I はじめに

本稿の課題は，1890年商法（以下旧商法とよぶ）の会社部分施行前において，地方官庁が実 施した株式会社に対する設立規制の内容とその意義を，株主の有限責任という観点から，東京 府・大阪府を例に明らかにすることである(1)。

社会的遊休資本の集中を目的とする株式会社は, 株式を発行し，かつ株主の責任が有限であ ることを基本的特質とする。日本では，所有者の有限責任か認められた株式会社のような組織 は，明治期まで存在せず，日本最初の株式会社は，1872年に制定された国立銀行条例に基づい て設立された国立銀行である。会社制度を紹介した『会社弁』、立会略則』といった書籍や, 1876年の国立銀行条例改正に伴う全国各地での国立銀行設立が，会社に対する知識を一般社会 に広める契機となった。その後，会社知識の普及に伴い，1877年からのインフレ期には，会社 は一種の流行になり，全国会社数が1881年の1,803社から，1882年の 3,336 社に増加した（図 1 参照)。しかし，会社設立の流行にもかかわらず，全ての会社に対する統一的な法令である会 社法は，整備の必要性を政府内部でも早く認識されながら，なかなか制定されなかった。それ は, 会社法は商法の一部であり, 商法の編纂にあわせて制定すべきであるとの見解に起因して

図 1 全国の会社数の推移

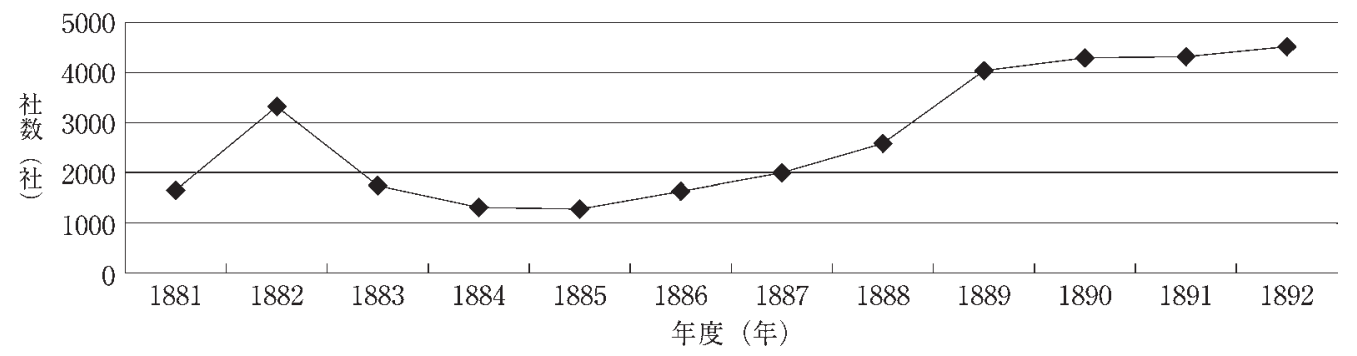

（出所）『統計年鑑』,『日本帝国統計年鑑』各年版より作成。

\section{経営史学 第44巻第 1 号（2009年 6 月） 58～77頁}

北浦貴士 (きたうら・たかし), 東京大学大学院経済学研究科博士課程 
いる。その商法は1890年に制定され，1893年に会社部分が先行して施行されたのである。

このように商法の編纂が遅れ，1872年から1893年まで商法の会社部分が存在しない状況で, 株主の有限責任制度に関する様々な問題が発生していた。有限責任に対する社会的理解がどの ように深化したのかを検討する上で，問題がどのように解決され，株式会社が設立されたのか を考察する必要がある。そこで，上記の論点を解き明かす 1 つの鍵として，株式会社に対する 設立規制に着目し，設立規制が株主の有限責任の普及に果たした役割を考察する。

1872年から1893年までの株式会社の成立と会社規制について，まず法制史研究が会社法制へ の関心から考察を加えている。福島正夫氏や利谷信義・水林彪氏は，1872年から1893年までの 会社法制や東京府及び大阪府の布令・布達の変化を検討した上で(2)，福島氏は，後述する 1880 年の「東京府布達甲第21号」の制定における設立届出制の採用から，東京府の会社政策が完全 な自由設立主義であったと指摘している。

また，日本経営史研究が，会社そのものへの関心から，会社企業の展開度合を探るため，会 社定款を検討している。宮本又郎・阿部武司氏は，旧商法の会社部分施行の前年までに設立さ れた50社の定款を分析し，株式会社の制度的要件をほぼ満たすものが多かったことから，株式 会社制度の構築を会社の自力での成功であると論じた ${ }^{(3)}$ 。

このような法制史及び日本経営史における研究を踏まえた上で，明治期日本における株式会 社の形成及び普及の過程を明らかにしたのが高村直助氏であり，氏の研究が本稿の直接的な先 行研究である(4)。会社規制について, 高村氏は府県レベルの布令・布達や会社への介入を検討 し, 宮本・阿部氏が明らかにした株式会社制度の構築を, 政府及び地方官の規制とそれへの民 間の対応の結果であると論じた(5)。また大阪府の法制的措置が，1886年から1889年までにおけ る紡績を中心とした大阪府の会社の活発な設立に一役を買っているとし，大阪府における規制 の先進性を指摘している( ${ }^{(6)}$ 。

しかし, 先行研究は, 府県による裁量的な規制の実施や有限責任の社会的普及に重要な意味 をもった発起人身元調の意義について何ら検討を加えていない。そのため, 発起人身元調に代 表される1872年から1893年までの規制の具体的内容及びその趣旨を再検討する余地があるよう に思われる。またそうすることにより，株式会社制度導入初期における有限責任の社会への普 及過程を照射することも可能になろう。加えて，1886年時点の銀行，鉄道を除く諸会社の払込 資本金額に関して，東京府が全国の約 $40 \%$ を占め，他府県を圧倒している。先行研究では，東 京府の規制は大阪府に比べ，その分析が薄いが，旧商法施行前の株式会社の成立と規制の関係 を明らかにする上で，東京府の規制の考察も不可欠であろう。先行研究による会社規制に対す る評価を再検証するためには，会社設立に関する史料を用いて，個別事例ではなく，多くの事 例を観察することにより，規制の全体的な特徵を把握する必要がある。

そこで，本稿ではまず会社行政の実態についてより実証的な研究を進めることを目的に，東 京都公文書館及び大阪市立大学所蔵の一次史料を用い，規制の内容を分析する。その上で，規 
制の趣旨を, 株主の有限責任と不可分の関係にある資本充実という観点から明らかにする。株 主が有限責任しか負わない株式会社では，会社債権者が債権を回収するために当てにできるの は，会社財産だけである。そのため，会社財産を確保することは，株主の有限責任とは表裏一 体の関係を有しているが(7)，会社財産確保を企図した制度の一つが資本充実である( ${ }^{(8)}$ 。

以上の検討に際し, 設立時の資本充実と密接な関わりをもつ債権者, 一般株主, 発起人の三 者からの分析が必要であると考える。株式会社では, 資本充実のためには, 出資の中心である 発起人による確実な払込が欠かせない。逆に, 発起人からの払込なしに株主の有限責任は社会 的に成立しえず，債権者保護の観点から無限責任しか認められない。実際，後述するように， 旧商法会社部分施行前には，有限責任が認女られないケースが存在したが，そのような状況下 では，一般株主は会社設立の中心的人物である発起人の資力やその経営能力を重視せざるをえ ない。そこで本稿では，従来の研究史から一歩踏み込んで，会社規制が三者間の関係をどのよ うに考量したのかについて検討を試みたい。

\section{II１872年～1887年における会社規制の概観}

1 設立認可手続の簡略化

旧商法の会社部分が施行される1893年までは, 政府や地方官の認可を得ることにより会社を 設立することが可能となる認可主義が採用されていた。会社の設立認可の過程に注目すると, 会社は次の 2 種類に分類することができる。1つは, 国立銀行のような政府の経済政策の遂行 上特に重要であるため, 特別に法令が定められ，それに基づいて設立された特別会社である。 もう 1 つは，特別な法令に基づかない一般会社である。

まず特別会社の代表例である国立銀行の場合, 発起人が提出した創立証書, 定款及び地方官 の奥書に基づいて, 紙幣頭が大蔵卿の承認を経て, 設立を認可した。また株主の責任について は，国立銀行条例第18条第12節に株主の有限責任が明記されていた。

一方，一般会社の設立認可は，1878年を境にして大きく変化する。1878年以前については， 1871年11月に府県の地方官の任務を定めた「県治条例」及びそれに付属する「県治事務章程」 の上款に従い，地方官が設立を認めるべきであると判断した場合，主務省に禀議し，主務省は 設立の可否について, 可能であれば決裁し, 決裁が困難な場合は太政官に判断を求めた上で, 設立を認可していた(9)。しかし1878年頃から，政府は商法が未制定であることを理由に，一般 会社に対して，人民相対に任せることにし，設立は認可しても，その会社について政府・地方 官庁は責任を負わないとの方針を示すようになった。また，1878年 7 月に「府県官職制」が制 定された。これは, 会社設立の事務手続の簡略化や会社設立の自由化を目的として, 地方官庁 が基本的に会社設立の認可を行うこととなり，会社政策が府県に任されたことを意味し た (10)。地方官庁が「事重大」と判断した会社は, 主務省が設立を認可するのに対し, 地方官 庁が「事重大」と判断しない会社は, 地方官庁が設立を認可した上で，後で主務省に報告する 
ようになった。

このような1878年発布の会社規制の緩和を，東京府は最も極端な形で受け入れ，1880年 3 月 23 日に「東京府布達甲第21号」を定めた ${ }^{(11)}$ 。「東京府布達甲第21号」から，東京府の認可形態 は次の 2 種類に分類できる。1つは, 東京府が定めた 4 業種（「水利堤防道路橋梁二係ル会 社」,「水陸運輸二係ル会社」,「保険二係ル会社」,「私立銀行並ビニ銀行類似ノ会社」）に該当 する会社である。この会社は, 府知事に設立願を出願して府庁の認可を必要とした。以下で は，これを「認可会社」とする。もう 1 つは，東京府が定めた 4 業種に該当しない会社であ る。この会社は, 府庁の認可を必要とせず，郡・区への届出を行うこととなった。以下では, これを「届出会社」とする。

東京府が認可会社と届出会社に分類して規制を実施した理由について，「放任ノ制ナル テ中ニハ人民ヨ詐欺スル如キ最モ怪ムへキ会社アリ。是ニ於テ爾後ハ公衆ノ利害二大関係アル モノタシテ出願セシメ, 然ラサルモノ八人民随意ニ任シ, 公然卜府庁ヨリ許可ヨ与へサルヘシ 卜ノ考案 $コ$ 以テ, 去ル十三年中二於テ出願スへキ種類 7 水利堤防道路橋梁水陸運輸保険等二係 ルモノトシ」(12)たとし，東京府は公衆の利害に大きく関係する会社以外は，人民相対に任せよ うとしていた。ここから，発起人による詐欺の危険性が高いことを認識しているにもかかわら ず，人民相対に任せ，基本的に対策を実施しないという東京府の基本姿勢を確認できる。

大阪府もまた，会社に関して，1878年発布の大阪府布達第94号「私設商社に関する件」にお いて，官許の会社を名乗り，一般の投資家を针誘して出資を促すような事例が確認できるが, そのような状況は「自治営業」の発展を妨げることとなるため, 今後このようなことがあれ ば，会社の営業を差し止めることとし，また不当の勧誘があった場合は府庁に届け出るように 諭旨している(13)。このように，大阪府も政府・地方官庁による設立認可を利用した事件に対 し，あくまで会社が自由に営業活動しており，政府及び地方官庁はその活動に関係ないという 方針を示したのである。

2 1882年からの不況期における詐欺事件の発生と司法による債権者保護

図 1 から分かる通り，1882年からの不況に伴い，会社数は1882年の3,336社から，1884年に は1,298社にまで減少した。このような会社の倒産原因として，会社法の未制定や規制の簡略 化に伴う多くの泡沫会社の設立があげられる。そして, 当時会社は設立してもすぐに倒産する ものとして，社会から敬遠される存在になっていたのである(14)。

また，発起人による詐欺事件が発生していた。当時，「世人概ネ，株式会社ノ発起アルヨ聞 クヤ実際其会社ノ内情习探穿セズシテ，単二発起人ノ姓名卜其会社ノ目的トニ重キヨ置」(15)い ており，誰が発起人であるかは重要であったが，詐欺師が，株式会社の設立を名目に，発起人 となり株主を募集し，資金を騙し取ることを目的に創業費として資金を徵収し，最終的には会 社を設立しないといった事例が存在した(16)。東京府でも，報酬として株を受け取ることを目 
的に会社を設立し，会社の経営には無関心であるというような問題が発生し(17)，島根県でも， 私腹を肥やすため，無資本にもかかわらず，会社を名乗り立派な規則を作って，その株主であ ると自称して，株主を募集していた事件が生じたのである(18)。

このような詐欺事件のほか，大阪府では，発起人が払込不能になって交替するという問題が 発生していた。「有限責任平野紡績会社」は1887年に，大阪府に「発起人進退御認可願」を提 出し，発起人の一人が株金を払い込むことができないため，発起人を交替した上で，旧発起人 が所有していた株券や責任を新発起人へ移す認可を求めた ${ }^{(19)}$ 。しかし，株金払込不能者は， 上記発起人 1 名にとどまらず，平野紡績は，大阪府に払込不能株及びその処分方法に関する臨 時総会決議案を提出した ${ }^{(20)}$ 。最終的には，無効となった株は949株，発行済株式総数の約 $19 \%$ にのぼり，発起人も100株以上の株主から 6 名を追加募集することとした。このような株金未 払込事件に対し，『聯合紡績月報』第十三号は，平野紡績会社の発起人の一部が，株金を払い 込まないため，苦情が多く出ているが，株金未払込は，起業の進捗を妨げるものであったと記 述している ${ }^{(21)}$ 。設立時の株金未払込は会社設立に悪影響を与えるが，特に発起人は株金の引 受割合が高いため，その影響は大きかったものと思われる。

そもそも, 会社法が存在しない状況において, 会社倒産時における株主・債権者間の法的解 決を図るのは，司法の役割であった。司法は，特別法に基づき設立した会社や政府の認可を受 けた会社を除いた会社は, 有限責任が社会的に定着していないため, 債権者保護が不十分であ り, 有限責任を認めると債権者を害すると判断した。そのため, 定款に株主の有限責任を記載 し, 府県により設立が認可された会社であっても, 善意の債権者に対して, 株主は有限責任を 主張できないという見解を示した(22)。司法は，旧商法会社部分施行までは一般会社の株主の 有限責任を認めず，取引の安全性を図ることにより債権者保護に努めたのである。また，この ような法的状況は, 当時の代表的経済雑誌である『東京経済雑誌』にも記載されていることか ら，一般投資家にも認知されていたといえよう(23)。

3 会社倒産時における会社残余財産分配からみた株主と債権者の利害調整

本節では，当該期の一般会社がおかれていた法的状況を踏まえ，会社倒産時における残余財 産の分配処理及び会社債務の整理から，有限責任の実際的な運用を確認する。

司法は，特別会社の代表例である国立銀行に対して，株主の有限責任を保証していたが，実 際の会社倒産時においても有限責任が適用された ${ }^{(24)}$ 。例えば,「第三十三国立銀行」は, 経営 不振から大蔵省に鎖店を届け出て，大蔵省より営業停止及び鎖店を命じられた ${ }^{(25)}$ 。大蔵省は 銀行の跡引受人を阿部泰蔵, 涉澤栄一, 未延道成とし, 銀行の債権者は, 跡引受人へ申し出る ように告示し, 期日までに申し出ない場合は残余財産の分配に加えなかった (26)。大蔵省によ る銀行鎖店であるため, 国立銀行条例第 96 条および第98条に基づき，没入公債証書の売却資金 の中から，同行発行の紙幣交換等のために金165,721円63銭 6 厘を支出し，これをもって銀行 
発行の紙幣を日本銀行紙幣に交換請求できる期間が設けられた ${ }^{(27)}$ 。紙幣交換後に，跡引受人 が資産負債勘定，決算分配勘定を決定し(28)，負債高843,026円 8 銭 2 厘に対して残余財産を分 配した結果，分配金はその負債高の約15\%に相当していた2(29)。

一方，一般会社の倒産時における会社債務の整理は様々であったが，具体的な事例として， 次の事例を確認できる。まず原則通り，株主全員により負担するケースがあげられる。例え

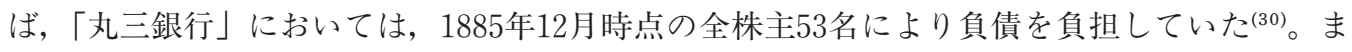
た，大株主のみにより会社債務を負担するケースも存在した。「久次米銀行」の場合，会社債 務のうち， 3 分の 1 を久次米家，3 分の 2 を大株主により負担しょうとする整理案が出され た ${ }^{(31)}$ 。この案自体は, 久次米家の反対により実現されなかったが, 当時そのような債務処理 案が存在したことがわかる。さらに,「北陸銀行」の場合, 有志者が債務の一部を負担してい た ${ }^{(32)}$ 。主な債権者と大株主が一致する場合は，どのように整理することが，その大株主にと つて望ましいかという観点から債務整理が実施されていた。「大坂製銅会社」の整理では, 債 権者である銀行が役員名義で同社株式の過半数を保有し，裁判になると銀行も被告になること から，債権者と株主間の協議の末，整理案が作成されていた ${ }^{(33)}$ 。

司法の判断により，善意の債権者に対する有限責任は否定されているにも関わらず，一般会 社が倒産した際，債権者が債権の一部しか回収できない事例が存在していたが，その理由は次 の 2 点によるものであると思われる。1つは，「大坂製銅会社」の債務整理で確認できるよう に, 主要な債権者が, 会社の大株主であった場合, 裁判所に出訴すると債権者自身が被告にな るため, 債権者は協議に基づいて整理方法を決定していた。もう1つは, 起訴した場合, 株主 に債権の償還を請求できるが，株主の財力がそしい場合には全額回収できないため，裁判によ る係争が必ずしも債権者にとって最善の方法ではなく, 債権者は会社と協議して債権の一部を 放棄したと考えられる。

以上より，1872年から1887年にかけて，一般会社の株主の有限責任は善意の債権者に認めら れず，債務整理は各会社によって大きく異なっていたという状況が明らかになった。では，次 章において，1886，1887年頃から実施されるようになった地方官庁による会社規制を具体的に 検討しよう。

\section{III＼cjkstart地方官庁による会社規制}

1 東京府・大阪府による布達の作成

会社条例が未制定であり，1882年からの不況で多くの会社が倒産するという状況に対し，東 京府は，その原因が設立時に会社が放任されているためであると考え，会社に対する方針を転 換し，会社条例が存在しないことに伴う弊害に対する措置を実施した ${ }^{(34)}$ 。その対策の 1 つが, 認可会社の範囲の拡大であり，1882年から1887年にかけて 6 業種が，新たに東京府による認可 の対象となった ${ }^{(35)}$ 。1887年に資本金10万円以上の会社が認可会社となるが，1890年時点で東 


\section{経営史学 第 44 巻第 1 号}

京府に存在する会社 347 社中, 資本金10万円以上の会社数は 147 社（42\%）であった。この時期 の認可会社の範囲の拡大により，1890年には半数近くの会社が認可会社であったと思われる。

大阪府布達第94号において，政府及び地方官庁は，会社の活動に関係ないという方針を示し た大阪府もまた，1886年に「合資結社営業取締規則」という布達を出し，会社に対する規制基 準を明確化した ${ }^{(36)}$ 。「合資結社営業取締規則」に基づいて，会社設立時には大阪府に対して出 願手続をとることが義務づけられた。さらに，規則が公布される前に設立された会社でかつ， 大阪府の認可を受けずに設立された会社も，事後的に大阪府の認可を受けなければならなくな った。この規則の制定により, 大阪府に存在する全ての一般会社に対して, 大阪府の認可が必 要となった。規則のうち本稿に直接関係する部分の趣旨を簡単に説明すると, 第 1 条第 2 は, 発起人及び発起人による負担額の明確化，第 1 条第 3 は，株主による株金の確実な払込である と思われる。第 6 条は, 会社責任制の明確化であり, イギリスの 1855 年「有限責任法」が, 会

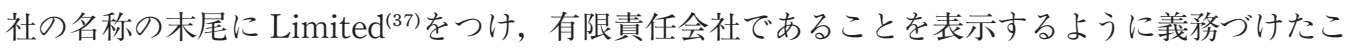
とに倣ったものであるとする見解も存在する(38)。第 7 条は, 破綻処理の明文化であると考元 る。このように, 大阪府では「合資結社営業取締規則」により，株式払込の促進，株主の責任 や会社債務整理の明確化を趣旨とする布達が制定されたのである。

\section{2 東京府の会社規制}

（1）設立時及び定款改正時における規制

本節では，東京府の設立時及び定款改正時における規制の運用を具体的に考察する。以下で の分析に先立ち，使用する史料を簡単に紹介する。東京都公文書館所蔵の一次史料から，東京 府文書『原何届録・会社規則』(明治20 22年) 及び『庶政要録・会社定款規約』(明治23 26 年）を用いる。『願伺届録・会社規則』及び『庶政要録・会社定款規約』は，東京府に提出さ れた会社設立願や定款改正願に対する東京府の認可史料を年代別に緅ったものである。本稿で は，東京府の設立時及び定款改正時における規制の具体的な運用を，『願伺届録・会社規則』 (明治22年) を中心に分析し，その他の史料についても，適宜参照した。

東京府の会社は，認可会社及び届出会社に分類できるため，まず認可会社に対する設立規制 から分析する。東京府は認可会社の設立願に対して, 「書面会社設立ノ儀, 追テ一般会社条例 制定相来候迄，人民ノ相對二任七候条，其旨可相心得事」(39) という指令案を作成し，商法施行 までの間，人民相対に任せることをもって，設立を認可していた。また東京府は，発起人身元 調を実施するために,「会社設立願二付身元照会按」(40)を作成し, 加えて定款を附箋の通りに 訂正するように指示していた(41)。このように設立時における東京府の会社への主要な介入手 段は, 発起人身元調と定款訂正指示であった ${ }^{(42)}$ 。発起人身元調とは, 会社の設立者である発 起人の財産や職業等を調査したものをいい，定款訂正指示とは，東京府が定款に不都合な点が あると考えた場合に，その点を訂正するように指示したものをいう。 
表 1 東京府による発起人身元調および定款訂正指示の実施状況

\begin{tabular}{|c|c|c|c|c|c|c|c|c|c|c|}
\hline \multicolumn{9}{|c|}{ 単位 社 } \\
\hline 認・無 & 認・身 & 認・訂 & 訂・身 & 計 & 届・無 & 届・訂 & 計 & 改・無 & 改・訂 & 計 \\
\hline 30 & 26 & 5 & 12 & 73 & 68 & 12 & 80 & 65 & 6 & 71 \\
\hline
\end{tabular}

（注） 表中の「認・無」は認可会社で，無条件で設立された会社を，「認・身」は認可会社で 身元調のみを受けた会社を，「認・訂」は認可会社で定款訂正のみを指示された会社を， 「訂・身」は認可会社で身元調を受け, 定款訂正を指示された会社を,「届・無」は届出会 社で指示を受けなかった会社を，「届・訂」は届出会社で定款訂正を指示された会社を， 「改・無」は無条件で定款改正願が認められた会社を，「改・訂」は定款改正時に定款訂正 を指示された会社をさす。

（出所）東京都公文書館所蔵『願伺届録・会社規則』, 『庶政要録・会社定款規約』より作成。

次に，届出会社に対する設立規制についてであるが，届出会社は，府の認可を必要としない が，東京府が，届出会社の定款訂正を指示していた(43)。このように，旧商法施行前の東京府 の届出会社に対する実際の規制は，自由放任ではなく，定款を検査し，事後的な定款訂正を指 示するものであった。

また，東京府の会社規制は，定款改正時にも実施されていた。認可会社が定款を改正する際 に，改正事項に不都合がある場合には，府はその点を訂正するよう指示していた ${ }^{(44)}$ 。届出会 社は，設立時と同様，認可を必要とせず届出のみであったが，東京府はその定款をチェックし ていた。

ここで，東京府の認可会社及び届出会社に対する発起人身元調，定款訂正指示の実施状況を 確認しょう (表 1 参照)。分析対象となった東京府の会社は, 認可会社73社 (48\%), 届出会社 80 社（52\%）に分類できる。認可会社73社の内，東京府が身元調を実施した会社は38社（52 \%)であった。また定款訂正を指示した会社は17社（23\%）であった。一方，届出会社 80 社の 内発起人身元調を実施したのは 0 社であったが，定款訂正を指示した会社は 12 社（15\%）であ った。定款改正願を提出した認可会社は71社あったが，そのうち定款訂正を指示した会社は 6 社 $(9 \%)$ であった。以上から, 東京府は, 認可会社の設立時において, 約半数の会社に発起 人身元調を，約 $20 \%$ 会社に定款訂正指示を実施していたことが明らかになった。

（2） 発起人身元調及び定款訂正指示の内容とその趣旨

次に，東京府が実施していた発起人身元調及び定款訂正指示の内容を具体的に検討した上 で，その趣旨を検討しょう。まず発起人身元調について，その調査項目は，「平素品行ノ良 否」,「業体」,「所有不動産ノ概価格」，「身代見積ノ高」，「現在負債ノ為メ被告トナリシヤ否」 の 5 項目，もしくは「雇人アラ八其人員」という項目を加えた 6 項目であった。調査結果を分 析すると,「業体」，「所有不動産ノ概価格」，「身代見積ノ高」，「雇人アラ八其人員」について は, 発起人各人の状況が記載されていた一方, 「平素品行ノ良否」については, 品行が悪いと いう記載はなく，「現在負債ノ為メ被告トナリシヤ否」についても，被告となっているという 


\section{経営史学 第 44 巻第 1 号}

事例は確認できなかった。

また調查を実施していたのは，東京府ではなく，発起人が東京市に在住する場合は区に，東 京市以外である場合は郡や町に，そして東京府以外の地域に在住している場合は在住している 府県に, 東京府が依頼し, 調査結果の報告を受けていた。実際には, 差配人と呼ばれる人達 が，身元調を実施している事例を確認できる(45)。区が差配人に身元調を依頼し，その報告を 受けていた。調査主体である差配人は, 調査対象である発起人が, 所有し, 在住している番地 の担当であった。そもそも差配人とは, 不動産賃貸経営の代行者という点で，近世期の江戸に おける家守の後継者である（地主一差配人一借地人・借家人）。また，布告の通達・届出・戸 籍表作成等の行政末端事務を担っていた ${ }^{(46)}$ 。差配人による身元調の調查は, 差配人が当時担 つていた行政末端事務の 1 つであると考える。加えて, 差配人は, 調査対象となる不動産の管 理者であるため，「所有不動産ノ概価格」を調查する適任者であったと思われる。

発起人身元調の趣旨については，1884年頃に発起人による詐欺事件が発生しており，認可会 社の対象となっている公共性の高い業種を中心に，発起人による事件を防ぐことを目的に実施 していたと考える。また，一般会社の株主に対して，有限責任が必ずしも認められなかった状 況下では，発起人の経営能力を図る上での指標となる「業体」や出資可能な資力の有無がより 重要な意味をもったといえよう。

次に，定款訂正指示についてであるが，その趣旨として，定款は会社の根本規則であるた め, 会社に関する知識や経験をもつ東京府は, 定款訂正を指示することにより，定款の整備に 力を尽くすとともに，会社にとって好都合な制度を採用した定款ではなく，有限責任，株式， 機関といった株式会社の特質に基づいた定款作成を会社に促していた点があげられる(47)。

ここで，定款訂正指示の趣旨を踏まえた上で，東京府による定款訂正指示の内容を具体的に 検討しよう。本稿では，東京府の定款訂正指示内容を整理するにあたり，株式会社の特質に基 づいた定款作成への指導という観点から，「株式会社の諸機能に関する指示」と「その他の指 示」に大別した。その上で，「株式会社の諸機能に関する指示」を次の 3 つに区分する。第 1 は，「有限責任」である。「有限責任」とは，株主の有限責任に関係する訂正指示をいう。代表 例として，5株未満の株式については，売却及び譲渡を禁止するという「東京綿会社」の定款 に対する，府の条文削除指示があげられる。この削除指示の趣旨は，株主の投下資本回収の保 障であり，己れは株主の有限責任に起因するものである(48)。第 2 は，「株式払込」である。 「株式払込」とは，定款上の株式払込規定に関する訂正指示をいう。株式払込に関する規定は， 設立時に株主に対して株式の払込を促し，会社財産を確保するために設けられるものである。 代表例として，「東京薬品会社」に対する株式払込の期間及び払込の株主に対する通知方法を 明文化するように指導した府の指示があげられる。第 3 は，「機関」である。「機関」とは，株 主総会に代表される会社の機関に関する規定の訂正指示をさす。代表例として，株主の株主総 会招集権を過度に制限していた「東京綿会社」の定款に対する府の訂正指示があげられる。 
表 2 東京府の定款訂正指示の内容

\begin{tabular}{|c|c|c|c|c|c|c|c|c|}
\hline \multicolumn{2}{|c|}{ 株式会社の諸機能に関する指示 } & \multicolumn{4}{|c|}{ その他の指示 } & \multirow{2}{*}{ 合計 } \\
\cline { 1 - 7 } 有限責任 & 株式払込 & 機関 & 小計 & 定款改正 & 䛊字 & その他 & 小計 & \\
\hline 6 & 1 & 16 & 23 & 15 & 10 & 9 & 34 & 57 \\
\hline
\end{tabular}

(出所) 表 1 に同じ。

「その他の指示」については，「定款改正」，「誤字」，「その他」の3つに区分する。「定款改正」 とは，資本金の増減や株式払込期限の延長といった定款改正を伴う事項に対して，増減や延長 を行う際には，東京府の認可を必要とする旨の指示をさす。

表 2 から東京府の定款訂正指示内容を確認すると，定款訂正指示のうち，40\%は「株式会社 の諸機能に関する指示」であり，その内訳は，「有限責任」に関する指示が $26 \%$, 「機関」に関 する指示が $70 \%$ であった。この分析結果は，「有限責任」に対する定款訂正指示を通じて，例 えば定款上有限責任を採用しながら，少額出資の一般株主の譲渡を禁止するといった，会社に とって好都合な制度を採用した場合，府が修正を促したことを示している。また，「機関」に ついても，例えば会社が事務処理の簡略化を目的に，一般株主保護制度の 1 つである株主総会 招集権を過度に制限するような定款に対して, 一般株主保護の観点から，府が定款訂正指示を 通じて修正させていたことがわかる。結局, 定款訂正指示を通じて, 初めて会社は, 株式会社 の諸機能を踏まえた定款を作成することが可能だったのである。

（3）東京府の規制の特徵

東京府は，発起人身元調及び定款訂正指示の実施後，次の基準に基づいて会社設立の認可を 判断している。例えば「有限責任日本雑貨貿易商会」の場合, 発起人の 1 人の身代見積高が 55,000 円であり，資本金 100,000 円の 4 分の $1,25,000$ 円をその発起人 1 人で負担できること を理由に設立が浔可された。すなわち，資本金の 4 分の 1 を発起人が負担する財産を保有して いることが認可基準となっていた。一方で「東洋石油改良会社」の場合，資本金100,000円の 4 分の $1,25,000$ 円に対して, 発起人が保有する不動産価額が 3,000 円しかないため, 発起人 に資産を所有する者を加えて再度出願するように指示し, 設立認可願を一度却下してい た ${ }^{(49)}$ 。このように, 府が発起人の負担能力を認可の判断基準とするのは, 発起人は設立時に おける出資の中心であり，発起人に資力がなければ発起人が引き受けた株金が円滑に払い込ま れないためである。その趣旨は資本充実であると考える。

設立時の資本充実という観点からすると, 発起人身元調は, 発起人の職業や財産を府が直接 調査することにより，資本充実を担保する施策であった。一方，定款訂正指示は，有限責任や 株式払込に関する指示を通じて，資本充実と理論的に適合する定款を作成させるように指導す るという副次的な機能を有していた。結局，有限責任の前提となる資本充実を担保することを 趣旨とした東京府の規制は, 有限責任が認められなった当時の状況において, 府が株式会社の 
表 3 大阪府による発起人身元調および定款訂正指示の 実施状況

\begin{tabular}{|c|c|c|c|c|c|c|c|}
\hline \multicolumn{5}{|c|}{ 設立 } & \multicolumn{3}{|c|}{ 定款改正 } \\
\hline 身元調 & 訂正指示 & 身・訂 & 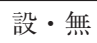 & 計 & 改・無 & 改·照会 & 計 \\
\hline 9 & 1 & 3 & 6 & 19 & 20 & 3 & 23 \\
\hline
\end{tabular}

（注） 表中の「身元調」は会社設立時に身元調のみを実施された会社を， 「訂正指示」は会社設立時に定款訂正のみを指示された会社を，「身・ 訂」は会社設立時に身元調を受け，定款訂正を指示された会社を， 「設・無」は会社設立時に無条件で設立が認可された会社を，「改・無」 は無条件で定款改正願が認められた会社を，「改・照会」は定款改正時 に府が改正理由を照会した会社をさす。

（出所）大阪市立大学所蔵『明治大正大阪市史編纂史料』より作成。

基盤を整えるための 1 つの政策であった。また実際の設立認可に関しては，発起人身元調及び 定款訂正指示の運用に関する布達及び布令レベルでの具体的な法令が確認できないことから， おそらく会社認可指令案を作成していた部署（1889年時点では東京府第一部農商課）が，裁量 的に認可を判断していたものといえよう。

\section{3 大阪府の会社規制}

（1）設立時及び定款改正時における規制

本節では大阪府の会社設立時及び定款改正時における規制の運用を，東京府と同様に考察す る。ここでも, 分析に先立ち, 使用する史料を簡単に紹介しょう。大阪市立大学所蔵の一次史 料から，『明治大正大阪市史編纂史料』の「設立関係書緅」を使用する。この史料は，大阪府 に提出された会社設立願及び定款改正願に対する府の認可史料を会社別に綴ったものである。 本稿では，1886年～1893年に会社設立願及び定款改正願を提出した株式会社を対象とする。た だ，史料は対象時期の全ての会社をカバーしていない上に，絶対的な件数が少ないが，このよ うな史料上の制約を考虑した上で，検討を加えることにする。

まず会社の設立時において, 大阪府も, 東京府同様発起人が充分な資産を保有しているこ と, 定款に問題点がないことを理由に, 設立認可を行い(50), 必要に応じて発起人身元調や定 款訂正指示を実施していた ${ }^{(51)}$ 。また定款改正時にも，府の認可を必要とし，大阪府がその改 正理由を会社に照会していた ${ }^{(52)}$ 。

ここで，大阪府による発起人身元調及び定款訂正指示の実施状況を確認しておく（表 3 参 照)。大阪府の会社設立手続19社の内，身元調を実施した会社が12社（63\%）であり，大阪府 は約 3 分の 2 の会社に対して, 発起人身元調を実施していた。また，定款訂正を指示した会社 は，4社（21\%）であった。大阪府の定款改正手続23社の内，詳細な調查を実施した会社は， 3 社（13\%）であった。ここから，大阪府の設立規制は，東京府の認可会社に対する規制と同 様の特徴をもっていたといえよう。 
表 4 大阪府の定款訂正指示の内容

\begin{tabular}{|c|c|c|c|c|c|c|c|c|}
\hline \multicolumn{2}{|c|}{ 株式会社の諸機能に関する指示 } & \multicolumn{4}{|c|}{ その他の指示 } & \multirow{2}{*}{ 合計 } \\
\cline { 1 - 7 } 有限責任 & 株式払込 & 機関 & 小計 & 定款改正 & 䛊字 & その他 & 小計 & \\
\hline 1 & 5 & 2 & 8 & 5 & 1 & 2 & 8 & 16 \\
\hline
\end{tabular}

(出所) 表 3 に同じ。

（2） 発起人身元調及び定款訂正指示の内容とその趣旨

（1）で論じた通り，大阪府の設立規制においても，発起人身元調と定款訂正指示が規制の中 心であった。では，大阪府における発起人身元調及び定款訂正指示の内容とその趣旨もまた東 京府と同様であったのだろうか。

まず発起人身元調の取調項目については，「平素品行ノ良否」，「動・不動産ノ有無」「受刑 ノ有無」，「身代限ノ有無」であった(53)。また，実施者についても，大阪府が実施するのでは なく, 郡や区に調査を依頼していた。そしてその趣旨は, 発起人による詐欺事件や未払込事件 を防止するとともに，設立時の資本充実を図ることであったと考える。

以上の分析から，大阪府における発起人身元調の内容及びその趣旨は，東京府と同様であっ たといえよう。ただ，調査項目については，大阪府では東京府が行っていた，発起人の「業 体」に関する調查を実施しておらず，発起人身元調の調査項目については，全国的な統一が図 られていなかった。そこから, 東京府及び大阪府各々が発起人身元調の実施項目を決定し，そ の運用も裁量的であったと思われる。

次に定款訂正指示であるが，その趣旨は，会社に関する知識や経験を有していた府が，会社 にとって都合のいい定款ではなく，株式会社の特質に基づいた定款作成を会社に促すことにあ り，東京府と同様であったと考える。では，大阪府の定款訂正指示の内容を，東京府での分析 に用いた 6 種類の分類方法に基づいて整理した表 4 から確認する(54)。大阪府で実施された定 款訂正指示のうち，50\%が「株式会社の諸機能に関する指示」であり，その内訳は，63\%が 「株式払込」に関する指示であった。東京府と比較した場合，大阪府は「株式払込」に関する 指示の割合が高かったが，それは「合資結社営業取締規則」第 1 条第 3 「資本入金の期限」 が，株式払込期限の定款への記載を要求している点が影響していると思われる。このように， 大阪府では，定款訂正指示の際，「合資結社営業取締規則」に基づいて指示した事例が確認で きる。ただ，「株式払込」に関する指示の趣旨は資本充実であるため，その意味では東京府と 大きく異なるものではなかったといえよう。

（3）その他の監督行為

大阪府は，発起人身元調及び定款訂正指示の他に，一般株主保護や，会社財産確保という観 点から，会社に対して監督行為を実施していた。例えば，「有限責任平野紡績会社」の設立手 
続では，大阪府は会社に計算予算書を提出するように指示し，その予算書の当否を判断するた めに，堂島紡績会社に対して平野紡績規模である五千鍾紡績の各種要件を提出させていた。こ のように大阪府が予算書及び五千錘紡績の各種要件を提出させたのは, 開業後会社が順調に成 長するのかを判断するためであると思われる。さらに大阪府は，会社に以下の「受書」を提出 させている(55)。

\author{
御受書 \\ 今般住吉郡平野紡績会社設立出願仕候二付テハ願意御採用ノ上八左ノ処二確守仕候 \\ 第壱項 一 工場落成機械全備ニシテ事業ニ着手スル迄八発起人退社八勿論処有ノ株券 \\ 売買不仕候 \\ 第武項 一 資本金額十分/四以上払込以前二於テ其処有ノ株券 7 売買譲与セザル旨 \\ 諾スル者ニアラザレハ本社ノ株主タラシメス候
}

右御受申上候也

「受書」から，大阪府は，第 1 項において発起人に対して，事業開始まで発起人を辞任する こと及び株券を譲渡することを禁止させ，第 2 項に記載されている他の一般の株主とは異なる 取扱いをした。これは, 発起人が設立時に期待を煽って, 売り逃げすることを防止するためで あろう。このような施策は, 有限責任が一般株主に必ずしも認められていなかった状況下で,

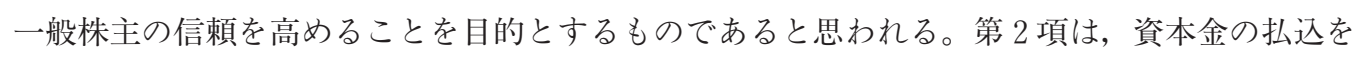
行わずに株式売買を行うといった投機を防止することを趣旨とし，資本充実に資する規制であ ると考える。

また，大阪府は定款改正時に，定款改正理由を照会していた。例えば，「有限責任岸和田製 油会社」は，株式の払込期限を1889年 5 月から1890年 6 月に改正するために，定款改正願を大 阪府に提出した ${ }^{(56)}$ 。これは,「合資結社営業取締規則」第 1 条第 3 に基づいて記載された定款 規定の改正である。この改正願に対し, 大阪府は, 改正願に記載されている理由では認可の判 断材料として充分ではないため, 会社に詳細な理由書を提出するように指示した。最終的に, 会社から現在の払込金だけで営業を行うことができるため，払込期限を延長するとする理由書 が提出され，「将来営業之見込」という判断から，定款改正は認可された。

以上から，大阪府は，将来の営業見込み，会社の維持という点を定款改正願の認可に関する 判断根拠にしていたことが明らかになった。そもそも，払込期限の延長は，設立時における会 社財産の確保を遅らせるものであるが, 将来にわたり営業が行われていれば, 債権者は債権を 回収することができるため, 大阪府の将来の営業見込みに基づく払込期限の延長認可は, 債権 者保護に資する政策であったといえよう。

結局, 大阪府における会社規制, 発起人身元調・定款訂正指示・その他の監督行為もまた, 
表 5 東京府の認可会社の設立認可に要した日数

\begin{tabular}{|l|c|c|c|c|c|c|}
\hline & 3 日以内 & $4 \sim 7$ 日 & $8 \sim 15$ 日 & $16 \sim 30$ 日 & 31 日 & 計 \\
\hline 会社数 & 15 & 13 & 10 & 22 & 13 & 73 \\
\hline 身元調 & 0 & 0 & 5 & 21 & 12 & 38 \\
\hline
\end{tabular}

（注）表中の「身元調」は,「会社数」の内, 身元調を実施している会社 をさす。

（出所）表 1 に同じ。

表 6 東京府の発起人身元調に要した日数

\begin{tabular}{|c|c|c|c|c|c|}
\hline & 3 日以内 & $4 \sim 10$ 日 & $11 \sim 20$ 日 & 21 日 & 計 \\
\hline 東京市内 & 1 & 57 & 29 & 7 & 94 \\
\hline 市以外の東京府内 & 0 & 8 & 6 & 0 & 14 \\
\hline 他府県 & 0 & 0 & 1 & 9 & 10 \\
\hline
\end{tabular}

(出所) 表 1 に同じ。

府県の認可では有限責任が認められない状況下において，府による株式会社制度の基盤整備の ための施策であったと考える。

4 地方官庁による規制の効果

最後に，前節までの具体的な規制の運用に関する検討を踏まえ，地方官庁による規制の効果 を確認する。東京府による設立規制に対して, 「有限責任帝国馬匹会社」は設立認可が下りな い原因が，発起人財産の不足にあるのなら, 数百人の賛同者が存在し, さらに発起人を増加さ せることも可能であるため, 至急認可してくれるように, 東京府に「御伺」を提出し，迅速な 認可を求奴。会社がこのように迅速な認可を求める背景には, 迅速な認可は, 早期の営業を 可能とするため, 認可の迅速化は会社にメリットがあったという点があげられる ${ }^{(57) 。}$

では，東京府の設立認可は本当に日数を必要としたのかを，表 5 から確認してみる。ちなみ にここでいう認可に要した日数とは, 設立願が提出されてから, 認可の指令案が作成されるま での間をさす。東京府が会社の設立を認可するまでの日数は，3 日以内が15社（21\%)，4 7 日が13社 (18\%)，8～15日が10社（14\%)，16〜30日が 22 社（29\%)，31日以上が13社（18 \%)であった。このうち，身元調を実施している会社が占める割合は，3 日以内，4〜 7 日が $0 \%$ に対して，8～15日が50\%，16〜30日が95\%，31日以上が92\%であった。

つづいて, 表 6 は東京府が発起人身元調に要した日数を示している。東京市内と東京市内以 外の東京府内の地域ではあまり差が見られず，4～10日の割合が最も高く，ついで，11〜20日 の割合が高かった。また，他府県については，21日以上の割合が $90 \% を$ 占めており，他府県の 調查は, 東京府内の調査に比べて日数を要した。表 5 及び表 6 から, 東京府は身元調に時間を かけていたために，設立認可に日数を要していたことが明らかになった。

ただ，会社からの迅速な設立認可を求める要求に対し，東京府はその要求を無視するのでは 
表 7 大阪府の設立認可に要した日数

\begin{tabular}{|c|c|c|c|c|c|}
\hline 3 日以内 & $4 \sim 7$ 日 & $8 \sim 15$ 日 & $16 \sim 30$ 日 & 31 日 & 計 \\
\hline 1 & 2 & 4 & 9 & 3 & 19 \\
\hline
\end{tabular}

(出所) 表 3 に同じ。

なく, 次の 4 つの施策を実施し, 設立認可の迅速化を図った。第 1 は, 身元調に対する調查期 限の設定である。東京府は，「身元調照会案」において，身元調を迅速に実施するため，例え ば「御取調来ル二十日迄二御回答相来度候也」というように，期限を設定していた。第 2 は, 東京府在住の発起人からの身元調の優先的実施である。調査期間の短い東京府下の住民を優先 し, 日数を要する他府県の発起人に対する調查を後回しにしていた ${ }^{(58)}$ 。第 3 は, 一部の発起 人のみの身元調の実施や以前調查した発起人の調査の省略である。「本願八例ニヨリ発起人ノ 内府下住民ノ身元取調候処, 資本金八五万円ナルニ, 発起人ノ資力八通計四万六千余円二相成 並シ発起人ノ内一人八，未調査区役所ヨリ回送無之モ，最早集元八充分卜認夕リ」(59)という 判断に基づき, 設立認可の指令案が作成されていた。第 4 は, 届出会社に対する届出制の採用 である。東京府では，「東京府布達甲第21号」により，4 業種（その後の認可範囲の拡大によ り最終的には 10 業種）以外の会社については，府の認可を必要とせず，郡・区への届出による 設立が可能であったが，このような届出制の採用は，迅速な設立認可を行うための施策であっ たといえよう。

また，大阪府でも，東京府と同様に，認可に時間を要したため，会社側から迅速な設立認可 を求める声が存在した ${ }^{(60)}$ 。しかし大阪府では, 東京府とは異なり, 設立認可の迅速化を企図 した政策を実施するようなことはなかった。では，大阪府でも，設立認可に要した日数を確認 しょう（表 7 参照）。大阪府が会社の設立を認可するまでの日数は，3 日以内が 1 社（ $5 \%)$, 4 ～ 7 日が 2 社 (11\%)，8１5日が 4 社（21\%)，16〜30日が 9 社 (47\%), 31日以上が 3 社 (16\%) であった。東京府と比較するとあまり差がないが， 3 日以内の割合は大阪府より東京 府の方が高く，一方，8～15日，16〜30日，31日以上の割合は大阪府が東京府に比べ高いとい う結果が出た。このような結果が出た背景には, 日数を要する身元調について, 東京府が調査 途中での中止や調査の一部省略を実施していた点があげられる。

資本充実を企図した地方官庁による規制は，日数を要するという問題があったが，有限責任 の社会的普及について一定の効果があったと考える。それを示すのが，東京控訴院の一般会社 の有限責任に対する見解の変化である。先述の通り，1887年の「モリソン商会事件」では，東 京控訴院 ${ }^{(61)}$ は, 府県による設立を認可された会社に対して, 善意の債権者に対する株主の有 限責任を認めていなかった。しかし，旧商法会社部分施行前年の1892年に争われた「中村良春 対早矢仕有的事件」では, 従来の見解を変更し, 原始定款に有限責任を明示し, 府県庁の認可 を受けているか，または届出を行っているという要件をもって株主の有限責任を認める判決を 
下した ${ }^{(62)}$ 。これは, 府県により設立を認可された会社は, 充分債権者保護が図られているた め, 有限責任を否定してまで債権者を保護する必要がないと東京控訴院が判断したことを意味 する。最終的に大審院 ${ }^{(63)}$ では, 府県により設立が認可された会社の有限責任は認められなか ったが，控訴院の見解の変化は，1887年頃から1892年の地方官庁による規制が有限責任の社会 的普及に対して有用であったことを示しているといえよう。

\section{IV まとめと展望}

本稿において，旧商法会社部分施行前における府県レベルの会社規制の具体的な内容，その 趣旨及び会社規制が有限責任の社会的普及に対して有した意義に関して, 先行研究との関係か ら次の諸点が解明された。

先行研究により，1882年頃からの不況時における，会社法制の未制定や設立手続の簡略化に 伴う会社の倒産や発起人による事件の発生に対して, 東京府による認可範囲の拡大, 大阪府に よる規制基準の明示や紡績会社への個別的な規制の実施といった対応が明らかになっていた。

しかし，本稿において会社設立認可に関する府県史料を用い，具体的な規制の運用を検討し た結果，東京府，大阪府ともに先行研究において明らかではなかった規制が実施されていた。 すなわち, 東京府は, 認可会社の設立手続時に, 約半数の認可会社に発起人身元調を, 約 $20 \%$ の認可会社に定款訂正指示を実施し，大阪府もまた設立手続時に，約 $60 \%$ の会社に発起人身元 調を，約 $20 \%$ の会社に定款訂正指示を実施していたのである。

具体的な規制として実施されていた発起人身元調の趣旨は，発起人の財産調査により，設立 時における確実な払込を促し，資本充実を図ることにあった。もう1つの規制である定款訂正 指示の趣旨は，会社が自らの都合で作成した定款を，株式会社の基本的要件を満たすものに訂 正させることであった。このような定款訂正指示もまた，発起人身元調ほど直接的ではないも のの, 資本充実にとって副次的な効果が期待できる政策であった。さらに注目すべきは, 発起 人身元調及び定款訂正指示について, その具体的な運用内容を示す布令や布達が存在しなかっ た点である。そのため, 会社の設立を認可するかどうかの判断は, 設立認可の担当部署に委ね られていたと思われる。

結局，東京府及び大阪府での規制について，早期の株式会社の制度的整備を促したのは，先 行研究が明らかにしたような布令・布達の制定ではなく, 発起人身元調や定款訂正指示に代表 される府，郡・区，差配人による裁量的な規制の運用であったと結論づけられる。このような 府県レベルの規制は, 当時一般の会社が必ずしも有限責任が認められるわけではなかった中 で，株主の有限責任を社会的に運用させることを企図して実施されていたと考える。そしてこ のような政策の効果は，1887年には，府県の認可をうけた会社の有限責任を認めなかった東京 控訴院が，旧商法会社部分施行の前年である1892年には，有限責任を認めるという見解の変化 に現れているといえよう。 


\section{経営史学 第 44 巻第 1 号}

表 8 時系列でみた設立規制の変化

\begin{tabular}{|c|c|c|c|c|}
\hline & 商法の有無 & 設立時の規制 & 認可主体 & 設立時の規制内容 \\
\hline $\begin{array}{c}1886 \sim 87 \text { 年 } \\
\downarrow \\
1893 \text { 年 }\end{array}$ & なし & 認可主義 & 府県 & 発起人身元調＋定款訂正指示 \\
\hline$\downarrow$ & 旧商法 & 認可主義 & $\begin{array}{c}\text { 農商務省 } \\
\text { (調査は府県が実施) }\end{array}$ & 発起人身元調 + 定款訂正指示 \\
\hline$\downarrow$ & 明治商法 & 準則主義 & なし & なし \\
\hline
\end{tabular}

今後の展望としては，会社規制という観点から鑑みるに，旧商法会社部分施行を画期とする 通説的な会社法制の意義についても新たな解釈がありうると思われる。すなわち，表 8 におい て確認できる施行前後における規制内容の連続性である。

旧商法の会社部分が施行されると，株式会社は，設立時の認可主体が，府県から主務省へと 変更された。しかし，施行後での設立規制内容は，施行前と同様に府県による発起人身元調及 び定款訂正指示であり，施行前後で，大きな変化を確認できない。そもそも，旧商法におい て, 設立認可主義が採用された背景として, 旧商法会社部分施行前に会社設立に官許を必要と

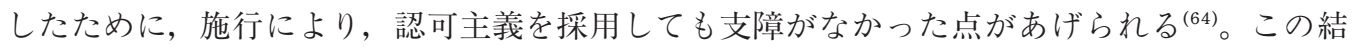
果，府県レベルで裁量的に実施されていた規制が，旧商法会社部分施行後においても同様に実 施されていくことになり，規制の趣旨についても，施行前後で変化がなかったのである。

一方，旧商法会社部分施行後においても，発起人身元調に日数を要した結果，政府，府県 は, 認可に日数を必要とした。この状況に対し, 発起人及び商業会議所は, 迅速な認可を求女 た。その結果，広く一般に会社知識が普及している状況で，無用の事務手続を省略することを 理由に，1899年施行の明治商法では，株式会社の設立時に政府の認可が不要である設立準則主 義が採用された。ただ，明治商法への移行のきっかけとなった，発起人身元調に日数を要する ために，発起人や商業会議所がその迅速な実施を求めるといった状況は，旧商法会社部分施行 後に発生したのではなく，施行前から孕まれていた問題であったことを，本稿にて明らかにし た。

\section{注}

（1）株式会社という用語そのものは, 旧商法により初めて用いられたものであり, 旧商法制定以前には, 社名 に株式会社と名付けた会社は基本的に存在しない。しかし, 実際には, 株式を発行し, 定款上に全出資者の 有限責任を謳った会社は存在していたため，本稿では，このような会社を便宜的に株式会社とよぶ。

（2）福島正夫「財産法 (法体制準備期)」『講座日本近代法発達史 $1 \rrbracket$, 勁草書房, 1958年, 利谷信義 - 水林彪 「近代日本における会社法の形成」高柳信一・藤田勇編『資本主義法の形成と展開 3 』東京大学出版会, 1973 年。

（３）宮本又郎・阿部武司「明治の資産家と会社制度」宮本又郎・阿部武司編『日本経営史 2 経営革新と工業 
化』岩波書店，1995年，277頁。

（4）高村直助『歴史文化ライブラリー 5 会社の誕生』吉川弘文館，1996年。

(5) 同上書, 135-136頁。

(6) 同上書, 165頁。

（７）前田庸『会社法入門 第11版補訂版』有斐閣，2008年，19頁。

（８）資本充実とは，資本金の額に相当する財産が現実に会社に拠出されなければならないという原則であっ

て，主に会社設立の場合に問題となる（前田前掲書，21頁）。

(9) 利谷・水林前掲論文，19頁。

（10）同上，48頁。

(11) 同上, 56頁。

（12）「会社条例編纂委員会 商社法第一読会会議筆記」『日本近代立法資料叢書17』法務大臣官房司法法制調查 部監修，1985年，157頁。なお，句読点は引用者により，以下も同様である。

(13) 高村前掲書，50頁。

（14）「第四回 農商務卿報告」『明治前期財政経済資料集成』第四集 (3)，103頁。

（15）「法典委員会 商法委員会議事要録」『日本近代立法資料叢書19』法務大臣官房司法法制調査部監修，1985 年，129頁。

（16）「会社条例編纂委員会 商社法第一読会会議筆記」，149頁。

(17) 同上，157頁。

(18) 同上，158頁。

（19）絹川太一『本邦綿糸紡績史』第四巻，日本綿業俱楽部，1939年，68-73頁。

(20) 同上書, 70頁。

(21) 同上書, 51頁。

（22）1887年の「モリソン商会事件」が代表例としてあげられる(『裁判粋誌』第 2 巻，141頁)。

（23）「会社条例速に制定せざるべからず」『東京経済雑誌』第15巻第355号，199頁。

（24）「東京第三十三銀行」の事例は，1892年のものであるが，1887年以前も同様の状況であったと考える。

(25)「東京第三十三銀行の営業停止」『東京経済雑誌』第25巻第616号，426頁。

（26）「第三十三国立銀行の官命鎖店」『東京経済雑誌』第25巻第624号，727頁。

（27）「鎖店銀行紙幣交換基金支出」『東京経済雑誌』第26巻第633号，137頁。

（28）「第三十三国立銀行」の残余残産の分配結果は，以下の通りである。

一 金二十四萬三千九百二拾九圓六十三銭八厘 総取立金

内

$\begin{array}{ll}\text { 金十萬八千七百六十五圓八十五銭一厘 } & \text { 先取権ノアル債主へ返金高 } \\ \text { 金五千四百七十六圓八十七銭 } & \text { 鎖店入費 } \\ \text { 金十二萬九千六百八十六圓九十一銭七厘 } & \text { 分配金 } \\ \text { (「鎖店第三十三銀行の清算」『東京経済雑誌』第27巻第675号，721頁) }\end{array}$

（29）「鎖店第三十三銀行の清算」

（30）「丸三銀行」『東京経済雑誌』第14巻第337号，490-491頁。

（31）「久次米銀行維持の決議」『東京経済雑誌』第23巻第578号，909頁。

（32）「北陸銀行の閉鎖」『東京経済雑誌』第14巻第344号，721頁。

（33）「大坂製銅会社の改革」『東京経済雑誌』第14巻第348号，861-862頁。 


\section{経営史学 第 44 巻第 1 号}

（34）「会社条例編纂委員会 商社法第一読会会議筆記」，157-158頁。

（35）1882年から87年にかけて東京府の認可対象になった 6 業種は以下の通りである。 漁業採藻二係ル会社（1882年 6 月15日甲第70号を以て追加） 貸倉荷預りニ係ル会社（1882年 9 月 1 日甲第124号を以て追加） 伊豆七島二係ル会社（1883年 6 月18日甲第32号を以て追加） 鉱山灯台電信二係ル会社（1886年 9 月27日東京府令第21号を以て追加） 資本金十万円以上ノ諸会社（1887年 3 月19日東京府令第13号を以て追加） 小笠原島二係ル会社（1887年 9 月 1 日東京府令第50号を以て追加）

(利谷・水林前掲論文, $59 \cdot 60$ 頁)

(36) 利谷・水林前掲論文, 60 頁。

（37）LTD.又は Ltd.と略記することがある。

（38）吉田準三『日本の会社制度発達史の研究』流通経済大学出版会，1998年，22頁。

（39）東京府文書『願伺届録・会社規則』（明治22年）東京都公文書館所蔵。以下東京府の会社に関する史料で, 特に出典を示していないものは同様である。

（40）「魁玉運搬会社」の「会社設立願二付身元照会按」は，以下の通りである。 （前略）其区内箱崎町武丁目壱番地若松啓治外四名ノ者，今般魁玉運搬会社設立ノ儀出願候二付本人身元左 ノ項目二拠リ御取調来ル二十日迄二御回答相来度候也 取調項目

一 平素品行ノ良否

一 業体

一 所有不動産ノ概価格

一 身代見積/高

一 現在負債ノ為メ被告トナリシヤ否（後略）

(東京府文書『願伺届録・会社規則』(明治22年) )

（41）例えば，「魁玉運搬会社」の事例があげられる。

（42）1890年に旧商法が制定されるが，旧商法制定によって，例えば農商務省の認可を受けるといった旧商法の 施行を先取りした規制は実施されておらず，府が旧商法制定以前と同様に発起人身元調及び定款訂正指示を 実施していた。そのため，本稿では，旧商法制定前と制定後に区分せずに分析を行っている。形式的な变化 としては, 認可を行う際の指令案が, 旧商法制定に伴い,「会社設立願之件八，商法施行ノ期迄人民ノ相対二 任ス」と変化した点があげられる。

（43）例えば，「有限責任共同商会」の事例があげられる。

（44）例えば，「新場有会社」の事例があげられる。

（45）例えば，「日本生命保険会社」の事例があげられる。

（46）森田貴子『近代土地制度と不動産経営』塙書房，2007年，23・46頁。

（47）『商法修正案理由書』東京博文館蔵版，1899年，104頁。当該史料は旧商法会社部分施行後のものである が，定款訂正指示の趣旨は，施行前も同様であったと考える。

（48）株主の有限責任を採用する会社において，一般株主は，責任が有限であることに照応して，会社との関係 が薄いため，自ら経営に当たろうとしないし，またそれは実際上不可能である。このような株主の地位から して，株主はその個性が重視されない。従って，株主が自由に交替することを認めても会社に不都合がなく， 株式譲渡は原則として自由とされる。また，株主は株式譲渡により，投下資本の回収を図ることができるの 
である。

（49）「東洋石油改良会社設立届 口達案」東京府文書『庶政要録・第 36 3 - 農商・工部・会社ノ部・第 1 3 〈第二課〉・明治 24 年』東京都公文書館所蔵。

（50）例えば，「有限責任大阪坩堝製造会社」の事例があげられる。

（51）例えば，「第一煉化製造会社」の事例があげられる。

（52）例えば，後述の「有限責任岸和田製油会社」の事例があげられる。

（53）「有限責任日本コークス会社設立関係書緅」『明治大正大阪市史編纂史料』大阪市立大学所蔵。

（54）各項目の内容は，東京府での分析と同様であるため，具体的な項目の説明及び事例の紹介については省略 する。

（55）「有限責任平野紡績会社設立関係書経」『明治大正大阪市史編纂史料』

（56）「有限責任岸和田製油会社設立関係書緅」『明治大正大阪市史編纂史料』

（57）「法典委員会 商法施行法議事速記録」『日本近代立法資料叢書20』法務大臣官房司法法制調查部監修, 1985年，36頁。

（58）例えば，「上五商会」の事例があげられる。

(59)「上五商会」の設立願に対する指令案の認可理由である。

（60）「有限責任平野紡績会社設立関係書緅」

（61）現在の高等裁判所に該当する。

（62）利谷・水林前掲論文, 78-79頁。

（63）現在の最高裁判所に該当する。

（64）「会社条例編纂委員会 商社法第一読会会議筆記」，161頁。 